\title{
PUHEENVUORO
}

\section{MIKÄ ON VIRUS?}

\author{
YRJÖ HAILA
}

Lyhyt vastaus: missä elämää, siellä loinen. Virus on universaali loinen.

Menestyksellisen loisen idea on asettua isäntäeliönsä sisään ("sisäloinen, endoparasiitti") tai kiinnittyä sen pinnalle ("ulkoloinen, ektoparasiitti") ja menestyä niin pitkään, että jälkeläiset hajaantuvat etsiytymään seuraavaan isäntään ennen kuin edellinen menehtyy. Virus on endoparasiitti, joka tunkeutuu isäntänsä solujen sisään ja kykenee kaappaamaan isäntäsolun metabolian omaan käyttöönsä; virus monistaa itsensä luvuttomaksi määräksi kopioita isäntänsä biokemiallista koneistoa käyttäen. Virus on loisen malli ("eksemplaari") vailla vertaa. Virus loisii elämää ylläpitävien prosessien sisällä. Virus syntyy, kun elämä syntyy.

Lyhyt vastaus on oikoinen. Perusteellisemman pitkän vastauksen antamista helpottaa se, että viime vuosina on ilmestynyt runsaasti kiinnostavaa virusten biologista merkitystä käsittelevää kirjallisuutta. ${ }^{[1]}$ Kirjallisuuden runsaus selittyy kahdella seikalla: Ensinnäkin viruskiinnostusta ovat luonnollisesti lisänneet virusten viime vuosina aiheuttamat pandemiat ja pandemian uhat: HIV-AIDS 1980-luvulta lähtien, Ebola (1976 lähtien; pahoja epidemioita 2014-16 Länsi-Afrikassa ja 201819 Kongon Demokraattisessa Tasavallassa), SARS (2002), "sikainfluenssa" (2009), MERS (2012), sekä Zika (2015-16). Lisäksi kollektiivisessa lähimuistissa on "Espanjan taudin" aiheuttanut influenssaviruksen muunnos, jonka käynnistämään pandemiaan (1918-20) sairastui ehkä neljännes maailman väestöstä ja tautiin menehtyi useita kymmeniä miljoonia ihmisiä. Viimeisin eli SARS-CoV-2 (2019-
20-?) on uusi tulokas tähän luetteloon. Sen aiheuttamaa pandemiaa analysoivaa kirjallisuutta tullaan lähivuosina julkaisemaan kosolti (ks. esim. Horton 2020).

Toinen viruskirjallisuutta rikastanut tekijä on se, että 1980-luvun loppuvuosista lähtien biologinen tietämys viruksista on lisääntynyt valtavasti sekä määrältään että ennen kaikkea laadultaan. Ei ole liioittelua sanoa, että virusten biologisen merkityksen selkiytyminen on tuottanut vallankumouksen sekä biologista evoluutiota että globaalia ekologiaa koskeviin näkemyksiin. Murroksen selittää virusten tutkimukseen soveltuvien tekniikoiden valtava kehitys. Virukset ovat olemattoman pieniä ja sitä paitsi "vapaasti” ympäristössä esiintyessään elottomia, kidemäisiä molekyylipartikkeleita. Niistä on mahdotonta saada minkäänlaista otetta ilman erittäin tehokasta välineistöä, aluksi elektronimikroskooppia ja nyttemmin laitteita, joilla voidaan selvittää suuriin näytteisiin sisältyvän geeniaineksen täsmällinen rakenne.

PITKÄN VASTAUKSEN ALKU:

$$
\text { VIRUSTUTKIMUKSEN HISTORIA }
$$

Johdatus viruksiin tavataan aloittaa esittelemällä tutkimuksen historiaa; sama piirre on tyypillinen monien nykybiologian tutkimusalueiden esittelylle. Syy on ymmärrettävä: etenkin molekyylitasoisen biologian perustavat löydöt on säännönmukaisesti tehty uusien, 
aiempaa vaativampien laboratoriomenetelmien avulla. Mutta menetelmien kehitys ei noudata mitään tutkimuskohteiden määrittämää luonnollista logiikkaa vaan siihen on aina sisältynyt merkittävä määrä satunnaisuutta. Tämän "satunnaisuuden" selvittäminen auttaa ymmärtämään nykyistä käsitteistöä.

Virustutkimuksen alkupisteessä on tupakan mosaiikkivirus (TMV), joka tuotti laajamittaista tuhoa eurooppalaisilla tupakkaviljelmillä 1800-luvun jälkipuoliskolla (Zimmer 2015, Crawford 2018). Hollantilainen kasvipatologi Adolf Mayer (1843-1942) sai selville, että taudin aiheutti jokin tuntematon tekijä, jonka voi siirtää kasvista toiseen sairastuneen yksilön kudosnesteen välityksellä. Pietarilainen Dmitry Ivanovski (1846-1920) sekä tämän oppilas hollantilainen Martinus Beijerinck (1851-1931) osoittivat, että tautia välittävä tekijä siirtyy läpi bakteeritutkimuksessa käytetyistä suodattimista. Ivanovski oletti, että taudin aiheuttavat bakteerien eritteet. Beijerinck sen sijaan arveli, että taudinaiheuttaja on jokin bakteereja pienikokoisempi elämänmuoto, jolle hän antoi nimen virus. Beijerinck oli oikeassa - joskin tämä saatiin vahvistetuksi vasta hänen kuolemansa jälkeen 1930-luvun lopulla elektronimikroskoopin avulla.

Elektronimikroskooppi teki myös mahdolliseksi selvittää TMV-viruksen rakenne: sillä on proteiinista koostuva kuori eli kapsidi sekä sen sisällä geneettistä informaatiota kantava ribonukleiinihapon (RNA) juoste. Ulkonaiselta rakenteeltaan tupakkamosaiikkivirus muistuttaa eräänlaista tankoa; sen paksuus on vain vajaat 20 nanometriä.

Erilaisia virustyyppejä on luvuton määrä. Niiden rakenteellisen moninaisuuden vuoksi järkevää arviota tyyppien kokonaismäärästä on luultavasti mahdotonta esittää: se on joka tapauksessa miljoonia ellei kymmeniä miljoonia. "Tyypillisten" virusten olennaisia osia ovat perintöaineksen juoste, jonka muodostaa aitotumallisia, monisoluisia organismeja loisivilla useimmiten RNA mutta esitumallisia bakteereja ja arkeoneja loisivilla deoksiri- bonukleiinihappo (DNA), sekä kapsidi, joka koostuu vaihtelevasta määrästä proteiineja. Virus infektoi solun siten, että ensin kapsidin proteiinit - yksi tai useampia - kiinnittyvät solukalvon reseptorimolekyyleihin; reseptorit välittävät kalvon läpi valikoidusti solun elintoiminnoille välttämättömiä aineksia. Seuraavaksi joko virus kokonaisuudessaan tai vain sen RNA- tai DNA-juoste tunkeutuu kalvon läpi solun sisään. Riippuen viruksen omien geenien koostumuksesta se joko tunkeutuu solun perintöaineksen sisältämään tumaan tai jää tuman ulkopuolelle. Olennaista on, että soluun siirtyy kaikki se aines, jonka virus tarvitsee ottaakseen käyttöön monistumisensa edellyttämän isäntäsolun koneiston.

Lisääntymiskierron yksityiskohdat vaihtelevat suuresti eri virustyyppien välillä. Mikrobien biologian käsikirja (Madigan \& Martinko 2006) antaa seuraavat viitteet: uusia viruksia voi syntyä kerrallaan solussa muutamasta muutamaan tuhanteen, ja viruksen monistumiseen solun sisällä voi kulua esimerkiksi 20-60 minuuttia (bakteerien virukset eli bakteriofagit) tai 8-40 tuntia (eläinsoluja infektoivat virukset).

Virusten tyypillisen elämänkierron olennainen piirre on vaihtelu täysin inaktiivisen kidemäisen partikkelin ja isäntäsolussa toteutuvan monistumisvaiheen eli replikaatiokoneen välillä (Solé \& Elena 2019). Replikaatio onnistuu ainoastaan isäntäsolun sisällä sen metabolista koneistoa hyväksikäyttäen. Inaktiivista, solun ulkopuolella esiintyvää olomuotoa Solé \& Elena kutsuvat erityiseksi "aineen olomuodoksi". Tällä he viittaavat siihen, että virusten inaktiivisen kidemäisen vaiheen tunnusmerkkinä oleva kapsidi rakentuu siihen sisältyvien proteiinien itseorganisoitumisen tuloksena; mitään "ulkoista" ohjeistusta viruksen rakenteelle ei ole. Rakentuminen toteutuu niiden entsyymien avulla, joita viruksen geenit saavat aikaan joko itse tai isäntäsolun avulla. Virusten perimään sisältyy tyypillisesti hyvin vähäinen määrä geenejä. DNA:n rakenteen selvittäneet Francis Crick ja James Watson päättelivät 
tällä perusteella jo 1950-luvulla, että virusten hahmo muodostuu automaattisesti niiden koodaamien proteiinien energeettisesti edullisina rakenteina - tästä virusten kidemäinen olemus. Tyypilliset rakenteet ovat sauvamaisia (kuten TMV-virus) tai säännöllisiä monikulmioita, yleisimpänä ikosaedri eli 20-tahokas.

Jokaisen virustyypin jatkumo edellyttää sitä, että siirtymät kiteestä replikaatiokoneeksi ja takaisin kiteeksi tapahtuvat sujuvasti. Mahdollisia välittymisen tapoja on lukemattomia, kuten SARS-CoV-2 viruksen välittymismekanismeja koskeva ihmettely on tuonut ilmi. Yleisesti ottaen viruksia on kaikkialla, ja ne kulkeutuvat kaikkiin eri suuntiin kaikin ajateltavissa olevin keinoin. Tosin edellinen vaatii olennaisen täsmennyksen: monet erittäin merkittävät virustyypit (esimerkiksi retrovirukset kuten HIV) ovat täysin integroituneita isäntäeliönsä solukkoon tai geenistöön. Leviäminen isännästä toiseen tapahtuu lähikontaktien kuten sukupuoliyhteyden välityksellä (HIV). Tyypillisiä elimistön sisällä asustavien virusten välittäjiä (eli vektoreita) ovat myös verta imevät niveljalkaiset (arthropodit) kuten sääsket ja punkit; saastunut injektioneula on hyönteisvektorin analogia.

Kun TMV-viruksen rakenne oli saatu selville, erilaisia virustyyppejä löydettiin nopeassa tahdissa lisää. Bakteereita infektoivat virukset (bakteriofagi tai lyhyesti fagi) muodostuivat perinnöllisyystutkimuksen tärkeäksi kohteeksi lähinnä siksi, että monia yleisiä bakteereita kuten Escherichia colia on helppo kasvattaa: ne lisääntyvät nopeasti, ja siten niitä infektoivia viruksia on myös ollut kätevästi saatavilla, kun eristämisen menetelmät oli opittu. Lisäksi fageihin kohdistuvaa geneettistä tutkimusta helpottaa se, että niiden geenit ovat paljaina näkösällä eivätkä tumassa sijaitseviin kromosomeihin kätkettyinä kuten monisoluisilla organismeilla.

Virusten luokittelu on oma ongelmansa. Virukset eivät muodosta "lajeja" klassisessa biologisessa merkityksessä, mutta niiden perustyypit ovat varsin vakaita. Nobel-palkittu virustutkija David Baltimore esitti 1970-luvulla virusten perintöaineksen koostumuksen ja replikaatiostrategioiden perusteella jaottelun, joka käsittää seitsemän päätyyppiä (Solé \& Elena 2019,13-15). Virukset ovat evolutiivisesti sidoksissa isäntäorganismeihinsa, joten niiden rakennetyypit ovat säilyneet samankaltaisina satoja miljoonia ellei miljardeja vuosia. Sen sijaan virusten perintöaineksen koostumus voi muunnella tavattoman nopeassa tahdissa, koska viruksilla ei ole RNA- tai DNAjuosteiden mutaatioita korjaavia mekanismeja. Influenssavirus on tästä malliesimerkki: epidemioita aiheuttavat viruskannat ovat joka vuosi hiukan aiemmista poikkeavia.

Pandemiat ovat muodostaneet olennaisen virustutkimuksen pontimen. Kun bakteerien ja virusten erosta päästiin perille, selvisi myös että virukset olivat aiheuttaneet monia pandemiaksi yltäneitä historiallisia katastrofeja; merkittäviä esimerkiksi isorokko, tuhkarokko, keltakuume, influenssa ja polio. Bakteereihin tehoavat antibiootit, mutta viruksiin ne eivät tehoa. Paras torjuntakeino on ennalta ehkäisevä rokote; isorokko ja polio on saatu siten tehokkaasti kuriin. Myös esimerkiksi tuhkarokkoa vastaan on olemassa tehokas rokote, mutta rokotevastaisuus on torjumiselle ongelma. Tuhkarokkoviruksen tehokkaan leviämisen vuoksi rokotteen antaman "laumasuojan" tulisi kattaa lähes koko väestö, mitä rokotevastaisuus vaikeuttaa.

Virusten aiheuttamien sairauksien historiasta on saatu selville kaksi erityisen mielenkiintoista piirrettä: pahimmillaan sairastumisesta seuraa elimistön systeeminen romahdus, kuten vuosien 1918-20 Espanjan taudin aikana tapahtui erityisesti nuorehkon ja hyväkuntoisen väestön keskuudessa. Romahduksen aiheuttaja oli oletettavasti elimistön immuunipuolustuksen ylireaktio, josta nykyisin käytetään nimitystä "sytokiinimyrsky". Toinen tärkeä piirre oli se, että osa väestöstä oli jo ennalta saavuttanut immuniteetin, eli sairastui vain lievästi tai ei lainkaan. Tällaisen reaktion taustalla voi 
olla jokin aiempi samankaltaisen mutta vaikutukseltaan lievemmän viruksen infektio.

Koko väestön mitassa immuniteetti on laumailmiö, mutta siihen voi sisältyä runsaasti yksilökohtaista ja täysin idiosynkraattista vaihtelua. Epidemiologisella tutkimuksella on vaikea päästä tällaisista yksityiskohdista perille, koska epidemiologia perustuu kokonaisia väestönosia kattavaan tilastolliseen analyysiin. Vaihtelu ei sellaisenaan ole ongelma; sitä voidaan hallita tilastollisesti mutta vain sillä edellytyksellä, että vaihtelua aiheuttavat taustatekijät tunnetaan ja voidaan ottaa analyysissä huomioon aineistoa jäsentävinä kategorioina (Saracci 2010). Tässä suhteessa esimerkiksi rokotuksesta mahdollisesti koituvat haitat, kuten sikainfluenssarokotteen aiheuttama harvinainen narkolepsia, ovat erittäin hankalia tapauksia.

\section{KIISTANALAISIA KYSYMYKSIÄ}

Virusten biologisen olomuodon tulkitsemiseen liittyy teoreettisia ja jatkuvasti kiistanalaisia ongelmia, joista Solé \& Elena (2019) nostavat esiin kaksi: ovatko virukset eläviä olentoja, ja mistä ne ovat peräisin?

Edellinen kysymys on tuottanut hankaluuksia, joiden ydin on hämmentävä: onko inaktiivista molekyylikidettä mielekästä pitää elävänä olentona? Kysymys on kuitenkin harhaanjohtava. Elämä ei rajaudu "eläviin olentoihin" erotettuna "ei-elävistä", vaan elämän olennainen piirre on tiivis vuorovaikutus olioiden ja niitä ylläpitävän ympäristön välillä. Elämä on ekologinen järjestelmä, jota ei voi mielekkäästi määritellä muuten kuin sisällyttämällä mukaan se ympäristö, josta elämänmuodot ovat riippuvaisia. Lukemattoman monien elämänmuotojen elämänkaareen sisältyy "eloton" vaihe, joka "virkoaa eloon" vain suotuisissa olosuhteissa: kasvien siemenet maaperän siemenpankissa, bakteerien ja planktoneliöiden lepovaiheet vesien pohjassa ja niin edelleen.
Virus on elämän olomuoto, jonka elämänkaareen sisältyvä inaktiivinen kidemäinen vaihe herää henkiin replikaatiokoneeksi vain sopivanlaatuisen organismin elävässä solussa.

Kysymys virusten alkuperästä on sen sijaan oikeasti hankala. Viruksia on oletettavasti ollut olemassa elämän alkuvaiheista asti; elämä syntyi maapallolla vähintään 3,7 miljardia vuotta sitten. Mitään suoranaisesti havaittavia fossiilijäänteitä ei tietenkään ole jäljellä elämän ensimmäisten vuosimiljardien ajalta. Sen sijaan geenikartoitukset ovat nykyisin niin tehokkaita, että niiden avulla voidaan paljastaa eri lajien ja lajiryhmien geneettisen koostumuksen yksityiskohtaisia eroja ja yhtäläisyyksiä. Kartoitustulokset tarjoavat keinon selvittää organismien geenistön evolutiivista historiaa. On selvinnyt, että perintöaines on siirtynyt lateraalisesti eliöiden ja eliöryhmien välillä paljon kattavammin kuin aiemmin on kuviteltu. Virukset ovat toimineet ja toimivat jatkuvasti lateraalisen geenisiirron agentteina liittämällä omia geenejään isäntäorganismiensa geenistöön ja siten, pidemmällä aikavälillä, myös siirtämällä geenejä yhdestä isäntäorganismista toiseen. ${ }^{[2]}$ Tällaisten evolutiivisten siirtymien seurauksena virusten ja eri lajiryhmiin kuuluvien "kehittyneiden" organismien geenistöt ovat sekoittuneet yhteen. Esimerkiksi ihmisen perimään sisältyvästä aineksesta noin puolet on peräisin retroviruksista, 10-20 prosenttia on yhteistä bakteerien kanssa, ja 5 prosenttia on peräisin sienistä (Moelling 2016). Onko tämä geenistöön sisältyvä evolutiivinen perintö pelkkää merkityksetöntä "rojua" (engl. "junk") kuten aiemmin tavattiin olettaa, vai onko sillä funktionaalista merkitystä? Kukaan ei tiedä.

Viruksilla on joka tapauksessa ollut erittäin suuri vaikutus biologisen evoluution kulkuun. Ne ovat satojen miljoonien vuosien aikajänteellä siirtäneet perintöaineksen pätkiä organismien ryhmästä toiseen ja siten itse asiassa konstruoineet nykyisten organismien perimät. Karin Moelling (2016) käsittelee tätä teemaa perusteellisesti teoksessaan $V i$ ruses. More Friends Than Foes. Hän toteaa, että 
monet erot erilaisten organismien perintöaineksen koostumuksessa saavat historiallisen selityksen, kun virusten rooli perintöaineksen siirtäjinä hyväksytään. Hän muun muassa esittää, että immuunijärjestelmä on saanut alkunsa perimään kiinnittyneiden retrovirusten puolustautumisesta "ulkopuolisia" eli niiden kannalta haitallisia viruksia vastaan. Moellingin näkemys virusten tärkeästä vaikutuksesta evoluution kulkuun on radikaali ja varmasti kiistanalainen, mutta pidän sitä perusteltuna.

Virusten ekologinen merkitys perustuu niiden runsauteen ja valtavan nopeaan monistumiskykyyn. Monissa artikkelilähteissä todetaan, että viruspartikkelit ovat erilaisia ympäristötyyppejä inventoitaessa osoittautuneet kertaluokkaa tai kymmentä kertaluokkaa runsaslukuisemmiksi kuin muut mikroorganismit. Solé \& Elena (2019) kuvaavat 2000-luvulla saatuja tuloksia virusten runsaasta esiintymisestä valtamerissä, missä ne ovat ylivoimaisesti runsaslukuisin eliötyyppi; kokonaismääräksi on arvioitu kvintiljoona $\left(10^{30}\right)$. Merten planktonin mikrobikasvustoja infektoivat virukset tappavat noin 20\% mikrobien koko biomassasta joka päivä. Toisin sanoen lois-isäntä-suhteet valtamerten planktonin bakteerien ja levien ja toisaalta virusten välillä tuottavat intensiivisen metabolisen kierron, jolla on globaalissa mittakaavassa huomattava vaikutus muun muassa hiilen siirtymiseen ilmakehästä merten kasviplanktoniin ja takaisin ilmakehään.

\section{LOPUKSI}

Mikä virus siis on? Käsitykseni mukaan vastauksia on vähintään kaksi, ja niiden keskinäisestä suhteesta ei vielä ole päästy kunnolla perille.
Ensimmäinen vastaus: Virus on ollut biologisessa evoluutiossa erittäin tärkeä sukupolvesta toiseen siirtyvän perintöaineksen eli geenien kokoaja ja välittäjä. Oletettavasti virukset ovat sisältyneet varhaisimpien elämänmuotojen joukkoon. Joistakin varhaisista elämänmuodoista on myöhemmin kehittynyt itsenäisiä, biosynteesin ja perinnöllisyyden mekanismit itsessään käsittäviä soluja, ja vielä myöhemmin (noin 600 miljoonaa vuotta sitten) monisoluisia organismeja. ${ }^{[3]}$ Virukset ovat alusta asti olleet läsnä (eläneet?) itsenäisten solujen ja organismien rinnalla/ sisällä universaaleina loisina.

Toinen vastaus: Virus pitää yllä globaaleja ekologisia ja biogeokemiallisia kiertoja. Varmaa on, että virukset ovat olennainen osa maapallolla esiintyvän elämän kokonaisuutta ja että maapallon elämä on riippuvainen viruksista sekä evolutiivisesti että ekologisesti. Virukset ovat kiinteä osa biosfääriä, jopa sitä ylläpitävä osa. Kuten Karin Moellingin (2016) kirjan otsikko toteaa: virukset ovat pikemmin ystäviä kuin vihollisia.

Elämä on varsin ahtaista ympäristön ennakkoehdoista riippuvainen itsensä uusintava ja ulkopuolisen energianlähteen vaativa prosessi ja sellaisena varsin haavoittuva. Kuitenkin maapallon elämä on osoittautunut sitkeäksi; se on selvinnyt ympäristöolojen dramaattisten muutosten kuten suurten ilmakehän koostumuksen vaihtelujen ja kylmyysjaksojen yli (Lenton \& Watson 2011). Resilienssi (engl. resilience) on elämän sitkeyttä kuvaava käsite. Maapallon elämän resilienssin avain on mikro-organismien runsaus ja monipuolisuus sekä niiden valtavan nopea lisääntymiskyky. Mikro-organismit muodostavat kokonaisuuden, joka on sopeutunut fysiologisesti erittäin nopeasti äkkinäisiin ympäristönmuutoksiin. Virukset ovat tämän joukon olennainen osa. 


\section{VIITTEET}

1 Olen käyttänyt tekstini tukena pääasiassa seuraavia teoksia: Zimmer (2015), Moelling (2016), Crawford (2018) ja Solé \& Elena (2019).

2 Varhaisimmat havainnot siitä, että bakteerit voivat vaihtaa keskenään geenejä jopa eri bakteerityyppien ("lajien") välillä, tehtiin jo 1900-luvun puolivälissä. Lateraalisen geenisiirron yleisyys kaikkien esitumallisten organismien piirissä selvisi 1990-luvulla: kuten Franklin Harold $(2014,25)$ toteaa, tuolloin alettiin "pienen liioittelun uhalla" ajatella, että esitumallisilla organismeilla oli vuosituhansien aikamittakaavassa

\section{KIRJALLISUUS}

Crawford, Dorothy H. (2018). Viruses. A Very Short Intoduction. 2nd Ed. Oxford University Press.

Harold, Franklin M. (2014). In Search of Cell History. The Evolution of Life's Building Blocks. The University of Chicago Press.

Horton, Richard (2020). The Covid-19 Catastrophe. What's Gone Wrong and How to Stop It Happening Again. Polity Press.

Lenton, Tim \& Andrew Watson (2011). Revolutions That Made the Earth. Oxford University Press. yhteinen geenivaranto. Geenien siirtymistä aitotumallisten organismien välillä pidettiin kuitenkin harvinaisena, ja monisoluisten organismien välillä jopa hyvin epätodennäköisenä.

3 Itsenäisesti menestyvien solu-organismien oletettu yhteinen kantamuoto tunnetaan nimityksellä LUCA (last universal common ancestor); täsmällistä ajoitusta sille ei voida antaa, mutta uskottavat arviot osuvat 3,2-3,5 miljardin vuoden taakse (Harold 2014 pohtii ongelmaa kattavasti).
Madigan, Michael T. \& John M. Martinko (2006). Brock Biology of Microorganisms. 11th Ed. Prentice Hall.

Moelling, Karin (2016). Viruses. More Friends Than Foes. World Scientific.

Saracci, Rodolfo (2010). Epidemiology. A Very Short Intoduction. Oxford University Press.

Solé Ricard \& Santiago F. Elena (2019). Viruses as Complex Adaptive Systems. Princeton University Press.

Zimmer, Carl (2015). A Planet of Viruses. 2nd Ed. The University of Chicago Press. 